International Journal of Environmental Research and

Public Health

ISSN 1660-4601

www.mdpi.com/journal/ijerph

Review

\title{
Bisphenol-A and Female Infertility: A Possible Role of Gene-Environment Interactions
}

\author{
XiaonaHuo ${ }^{1}$, Dan Chen ${ }^{1}$, Yonghua He ${ }^{2}$, Wenting Zhu ${ }^{1,3}$, Wei Zhou ${ }^{1}$ and Jun Zhang ${ }^{1,2,3, *}$ \\ 1 MOE-Shanghai Key Laboratory of Children's Environmental Health, Xinhua Hospital, \\ School of Medicine, Shanghai Jiao Tong University, 1665 Kong Jiang Road, Shanghai 200092, \\ China; E-Mails: 15216652683@163.com (X.H.); simpledandan1981@163.com (D.C.); \\ windy5490@163.com (W.Z.); zzsmile12@163.com (W.Z.) \\ 2 School of Public Health, Guilin Medical University, Guilin 541004, China; \\ E-Mail: hyhup3@hotmail.com \\ 3 School of Public Health, Shanghai Jiao Tong University, Shanghai 200025, China \\ * Author to whom correspondence should be addressed; E-Mail: junjimzhang@gmail.com; \\ Tel.: +86-21-2507-8871; Fax: +86-21-2507-8875.
}

Academic Editor: Paul B. Tchounwou

Received: 24 June 2015 / Accepted: 31 August 2015 / Published: 7 September 2015

\begin{abstract}
Background: Bisphenol-A (BPA) is widely used and ubiquitous in the environment. Animal studies indicate that BPA affects reproduction, however, the gene-environment interaction mechanism(s) involved in this association remains unclear. We performed a literature review to summarize the evidence on this topic. Methods: A comprehensive search was conducted in PubMed using as keywords BPA, gene, infertility and female reproduction. Full-text articles in both human and animals published in English prior to December 2014 were selected. Results: Evidence shows that BPA can interfere with endocrine function of hypothalamic-pituitary axis, such as by changing gonadotropin-releasing hormones ( $\mathrm{GnRH})$ secretion in hypothalamus and promoting pituitary proliferation. Such actions affect puberty, ovulation and may even result in infertility. Ovary, uterus and other reproductive organs are also targets of BPA. BPA exposure impairs the structure and functions of female reproductive system in different times of life cycle and may contribute to infertility. Both epidemiological and experimental evidences demonstrate that BPA affects reproduction-related gene expression and epigenetic modification that are closely associated with infertility. The detrimental effects on reproduction may be lifelong and transgenerational.
\end{abstract}


Conclusions: Evidence on gene-environment interactions, especially from human studies, is still limited. Further research on this topic is warranted.

Keywords: bisphenol-A; gene; epigenetics; female; infertility

\section{Introduction}

Female infertility is a complex disorder and can be caused by a number of factors including genetic, environmental and behavioral [1-3]. Since genomics at the population level are relatively stable over a short time span, environmental and lifestyle-related factors may play a more important role in the increase of infertility.

Endocrine disrupting chemicals (EDCs) are a class of chemicals, both natural and synthetic, that exist in the environment. They can interfere with the physiological function of the endocrine system [4] and adversely affect hormone balance by disrupting the secretion or regulation of hormones [5]. Therefore, EDCs have attracted more and more attention.

Bisphenol A (BPA), an EDC widely used as an industrial chemical, has estrogenic activity and was found in $95 \%$ of 394 adults urine samples from a reference population in the United States [6]. The European and US Food and Drug Administrations concluded that the current BPA levels may have no risk to the general population [7]. However, basic scientists contested that the entire population may suffer adverse health effects from current BPA levels [8-10]. Our review summarizes evidence on the association between BPA environmental exposure and female infertility, and focuses on the role of gene-environment interaction in this association.

\section{Methods}

A comprehensive search in PubMed was performed to identify relevant literature. The keywords included bisphenol-A, gene, epigenetics, female infertility, reproduction, and reproduction-associated keywords. All full-text articles and abstracts published in English prior to December 2014 were eligible for our review.

\section{BPA and Its Exposure}

BPA was first synthesized in 1891 [11]. The formula is $\left(\mathrm{CH}_{3}\right)_{2} \mathrm{C}\left(\mathrm{C}_{6} \mathrm{H}_{4} \mathrm{OH}\right)_{2}$ or $\mathrm{C}_{15} \mathrm{H}_{16} \mathrm{O}_{2}$ and the chemical name is 4,4'-dihydroxy-2,2-diphenyl propane [7]. It has been widely used in the manufacture of resins such as polycarbonate and epoxy. These chemicals are mainly used for the interior lacquer coating of food and beverage cans, thermal receipt paper, some dental sealants and fillings, detergents, soaps, lotions, shampoos, conditioners, and nail polishes [12,13].Over 3.5 million tons of BPA are produced a year worldwide and more than 100 tons are released into the atmosphere [14].

BPA is ubiquitous in the environment. Ingestion, inhalation and dermal absorption are the main routes of daily exposure [15]. The acceptable dosage of BPA, representing the safe exposure level in human, is $\leq 50 \mathrm{ug} / \mathrm{kg} /$ day [16]. In the general population, BPA has been detected in various tissues, including adult sera $(0.2-20 \mathrm{ng} / \mathrm{mL})$, placental tissues $(11.2 \mathrm{ng} / \mathrm{g})$, human breast milk $(0.28-0.97 \mathrm{ng} / \mathrm{mL})$, 
human colostrums (1-7 ng/mL), urine (1.12 ng/mL in women) [17], umbilical cord blood [18], saliva [19], follicular fluid ( $\sim 1-2 \mathrm{ng} / \mathrm{mL})$, and amniotic fluid [20]. In adults BPA is mainly metabolized by the hepatic glucuronidation pathway. The biologic half-life of BPA is approximately $6 \mathrm{~h}$, with almost complete excretion via urine in $24 \mathrm{~h}$ [21]. However, despite the rapid metabolism, BPA can accumulate in tissues for an extremely long time and experience a conjugation-deconjugation cycling. Thus, the excretion of partial BPA is delayed [22].

BPA can accumulate in reproductive organs [17] and act as an endocrine disruptor owing to its structural similarity to estrogen. It is a mixed agonist-antagonist to affect estrogens and other steroid hormones [23] such as antagonizing the hippocampal synaptogenesis induced by estrogens [24]. BPA could exert its impact at a very low dose. For example, BPA had estrogenic effects at $2 \mu \mathrm{g} / \mathrm{kg}$ [25] and may be more estrogenic in vivo [26]. Nevertheless, the estrogenic potency of BPA is 1000-100,000-fold less than that of estradiol [27].

Woodruff et al. [28] showed that the sensitive windows of human exposure to BPA include progestation (before, during and shortly after the formation of fertilized eggs), pregnancy, infancy, childhood and puberty. Fetuses are more vulnerable to the adverse effects of BPA due to an immature drug-metabolizing system [3].

\section{BPA and Female Infertility}

Infertility is generally defined as failure to achieve a successful pregnancy after 12 months or more of appropriate, timed unprotected intercourse [29]. It affects $10 \%-15 \%$ of couples [30]. In general, approximately $35 \%$ of infertility is due to female factors alone [31]. BPA can widely impact the female fertility through multiple pathways. More recent evidence demonstrated that BPA not only plays as "weak" estrogen, but also has many other potential biological activities [16].

\subsection{BPA and Hypothalamus}

BPA may cause developmental and/or functional deffects of the hypothalamic system, which could result in inability to achieve the reproductive capacity at puberty and maintain it during adulthood [32,33]. It was confirmed that irreversible alteration in hypothalamic-pituitary-gonadal axis caused by exposure to $500 \mu \mathrm{g} / \mathrm{kg} /$ day BPA in rats can lead to anovulation and infertility [34]. The underlying mechanism may invole the production of kisspeptin, a driving signal of gonadotropin release hormone $(\mathrm{GnRH})$ secretion [35,36]. For example, newborn rats treated with BPA at the doses of 100 and $500 \mu \mathrm{g} / \mathrm{day}$ had significantly diminished levels of prepubertalKiss 1 mRNA expression at the hypothalamus [37]. Paradoxically, Wang X et al. found that adult female mice treated with BPA $(20 \mu \mathrm{g} / \mathrm{kg})$ at proestrus could increase the Kiss 1 mRNA level. Such different regulatory actions of hypothalamic Kiss 1 system may be attributed to the sensitivity of the various components to the timing of treatment.

In addition, GnRH neurons themselves may be the target of EDC at the sensitive window (reviewed by Diamanti-Kandarakis et al.) [38]. For instance, prenatal BPA treated sheep (BPA $5 \mathrm{mg} / \mathrm{kg} / \mathrm{day}$ in cotton seed oil from day 30 to 90 of gestation) showed a significant decrease in GnRH mRNA expression prior to the expected onset of preovulatory LH surge [39]. 


\subsection{BPA and Pituitary}

BPA could directly affect the gonadotropin synthesis. Brannick et al. [40] found that mice administered with $50 \mathrm{ug} / \mathrm{kg} /$ day of BPA had decreased levels of gonadotropin mRNA, Gnrhr and $\mathrm{Nr} 5 \mathrm{a}$, key components of gonadotropin synthesis. Gnrhr is essential for signal transduction between the pituitary and the hypothalamus [41]. On the other hand, BPA also cause pituitary proliferation and an increase in gonadotroph number [40].

BPA may also disrupt kiss 1 system at the pituitary and affect gonadotropin release [35], suggested by findings that kisspeptin and GPR54 were co-expressed in rat gonadotrophs. Adult gonadectomized female rats supplemented with oestradiol showed an increase in Kiss1 mRNA levels but a decrease in GPR54 mRNA expression [42].

\subsection{BPA and Ovary}

BPA has various effects on the ovary. For instance, BPA exposure is associated with follicle loss [43]. It caused lower antral follicle counts [43], decreased oocyte survival [44], and even significant loss of primordial follicles by reducing ovarian follicular reserves in F3 generation females [45].

Polycystic ovary syndrome (PCOS) is the most common endocrinopathy of women of reproductive age. Its cardinal features are hyperandrogenism, insulin resistance and chronic anovulation [46]. The distinctive clinical features are hirsutism, menstrual disfunction and infertility [47]. Its etiology is not yet clear. Both human [48,49] and animal studies [34] have suggested a possible role of BPA in PCOS aetiopathogenesis. Recently, it was shown that women with PCOS had a significantly higher BPA level than women without PCOS [48,49]. Neonatal rats exposed to $500 \mu \mathrm{g}$ /day BPA developed PCOS-like syndrome in adulthood [34].

BPA has also been shown to increase testosterone $(\mathrm{T})$ concentration by stimulating ovaries to produce $\mathrm{T}$ [50] and inhibiting $\mathrm{T}$ hydroxylase activity [51]. Furthermore, it acts as a potent sex hormone-binding globulin binder, displaces androgens [51] and, therefore, increases serum free androgen index [49]. On the other hand, elevated androgen concentrations may down-regulate the UDP-glucuronosyltransferase activity and transcripts [52,53], resulting in a decrease in detoxification and clearance of BPA [34,54].

Additionally, BPA-exposure is linked to insulin resistance indices [49]. The impact of BPA on the development of insulin resistance was corroborated by animal data in that a single low dose of BPA $(10 \mu \mathrm{g} / \mathrm{kg})$ disturbed insulin action and glucose metabolism in adult mice [55].

\subsection{BPA and Meiosis}

Evidence shows that several key stages of oocyte development, including the onset of meiosis in the fetal ovary (prophase 1), perinatal follicle development, and adulthood resumption of meiosis are vulnerable to BPA [27]. In the fetal period, female mice exposed to low dose BPA (400 ng/day) had adverse effects on oogenesis by disrupting meiosis, resulting in synaptic defects and an increased rate of recombination. The perturbations caused chromosomally abnormal eggs and embryos when these fetuses reached adulthood [27]. Similar defects were observed in adult female rhesus macaques in that intrauterine exposure to BPA disrupted the meiotic prophase events by increasing the levels of recombination and 
centromeric associations between nonhomologous chromosomes [56]. An in vitro study of human fetal oocytes demonstrated that BPA was related to the disruption of meiotic maturation, spindle organization and chromosome alignment, and an increase in the rates of oocyte degeneration [57].

In vivo animal studies further demonstrated disturbances of BPA during the final stages of meiosis in adulthood. A study treated the juvenile females mice (20- to 22-day-old) with 20,40 , or $100 \mathrm{ng} / \mathrm{g}$ body weight/day BPA for 6-8 days and found a dose-related increase in the meiotic abnormalities, congressional failure and aneuploidy [58]. Pacchierotti et al. conducted acute $(0.2$ and $20 \mathrm{mg} / \mathrm{kg}$ for 1 day), sub-chronic $(0.04 \mathrm{mg} / \mathrm{kg}$ for 7 days $)$ and chronic studies $(0.5 \mathrm{mg} / \mathrm{L}$ in drinking water for 7 weeks) respectively. Only the chronic treatment group showed a significant increase in prematurely segregated chromatids. Eichenlaub-Ritter et al. repeated the subchronic exposure but failed to show a significant result. However, they observed an association between BPA and perturbed spindle morphology and lower rates of MII oocytes [59]. In the same vein, their in vitro study found that only high concentrations of BPA $(10 \mathrm{ug} / \mathrm{mL})$ induced congressional failure and meiotic arrest [59].

Similarly, human oocytes discarded by patients undergoing IVF/ICSI cycles were cultured in vitro with BPA $(20,200 \mathrm{ng} / \mathrm{mL}$ or $20 \mathrm{ug} / \mathrm{mL})$. Oocytes were less likely to progress to MII and more likely to degenerate. Bipolar spindles and aligned chromosomes were significantly decreased among MII oocytes [57]. The BPA interference was dose-dependent. These findings may partly explain the decrease in fertility reported in the last decades. However, it is worth noting that the concentrations of BPA $(20,200 \mathrm{ng} / \mathrm{mL}$ or $20 \mathrm{ug} / \mathrm{mL})$ in this study were much higher than the baseline BPA level $(1-2 \mathrm{ng} / \mathrm{mL})$ in human follicular fluid [20]. Further studies are needed to confirm whether an environmental relevant dose in accordance with the human natural exposure may cause adverse effects.

\subsection{BPA and Oviduct}

The main effect of BPA on the oviduct is progressive proliferative lesions (PPL). Newbold et al. treated neonatal mice with BPA $(10,100$ or $1000 \mu \mathrm{g} / \mathrm{kg} /$ day) and found that all groups had PPL in the oviduct [60]. In another study, gestational mice were exposed to BPA at 0.1, 1, 10, 100, or $1000 \mu \mathrm{g} / \mathrm{kg} /$ day. PPL was observed in all groups [16].

\subsection{BPA and Uterus}

Animal studies have demonstrated that prenatal exposure of mice to BPA could elicit atypical hyperplasia and stromal polyps of the uterus [16] and endometriosis-like phenotype [61]. However, human epidemiological studies did not confirm these associations [62-64].

Additionally, experimental studies suggested that BPA exposure could impair the uterine receptivity [65-67], which is important for successful embryo implantation. A study showed that exposure of pregnant mice to BPA $(0,0.025,0.5,10,40$, and $100 \mathrm{mg} / \mathrm{kg} /$ day $)$ during gestation days 0.5 to 3.5 resulted in defective uterine receptivity in the $100 \mathrm{mg} / \mathrm{kg}$ /day BPA-treated group [67]. Female mice exposure to BPA (6.75 and $10.125 \mathrm{mg}$ /animal) on days $1-4$ of gestation altered uterine morphology [68] and significantly reduced the number of implantation sites [69]. However, a very recent human epidemiological study did not support these results. Minguez-Alarcon et al. found no association between urinary BPA concentrations and in vitro fertilization (IVF) outcomes, including endometrial wall thickness, embryo quality, fertilization rates and implantation [70]. The discrepancy 
between animal and human findings may be attributed to BPA dose, exposure time and method between laboratory studies and epidemiological studies.

\section{BPA-Gene Interaction}

In the post genome era, gene-environment interactions have become a hot research topic [71]. Exposure to environmental factors, mainly nutritional, chemical and physical factors, potentially alters gene expression and changes the epigenome that can modify adult disease susceptibility and lead to disease phenotype [72,73].

While most previous animal and human studies examined the direct effect of BPA exposure on adverse pregnancy outcomes and infertility, little research has explored the role of BPA-gene interactions. Even the limited studies mostly focused on male rather than female infertility. Available evidence suggests that gene-environment interaction may be one of the major contributors to female infertility, and have lifelong [74] and transgenerational impact [75]. However, the mechanisms of gene-environment interactions are not yet fully clarified [72].

BPA was originally thought to work via binding to estrogen receptors (ERs) and triggering agonistic effects by mimicking hormonal action [76]. For instance, BPA selectively binds with classic ERs (ESR1 and ESR2) and acts as an ER modulator [77,78]. ESR1 and ESR2 play a significant role in the events of steroidogenesis, the growth of follicle, ovulation, and endometrial cycle [79]. In an in vivo mice study, BPA up-regulated mRNA expression of ESR1 gene by 2.85-fold while the expression of ESR2 gene showed no significant difference [80]. However, another in vitro study that exposed human fetal oocytes to BPA showed that the expression of ESR2 gene was as up-regulated as ESRI and ERR [ [81].

However, evidence from other systems now reveals that BPA can also affect gene expression directly and/or to impact epigenetic modification of fertility-related genes [82-84]. For example, in adult men, the gene expression of ESR2 and ESR1 increased in men with higher urinary BPA concentrations [85]. Caserta et al. [79] investigated 111 women aged 18-40 years, who were affected by primary infertility. The gene expression of nuclear receptors (ESR1 and ESR2), androgen receptor (AR), pregnane $\mathrm{X}$ receptor $(P X R)$, aryl hydrocarbon receptor $(A h R)$, and peroxisome proliferator-activated receptor gamma $(P P A R \gamma)$ was analyzed as biomarkers in peripheral blood mononuclear cell. A positive correlation was found between BPA levels and ESR1, ESR2, AR, AhR, and PXR expression, while $P P A R \gamma$ expression did not show any meaningful difference (Table 1). These findings were confirmed in another small study [86] and supported the hypothesis that BPA acts on nuclear receptor (NR) through disturbing hormone response pathways and/or steroidogenesis [79] and, therefore, affects female infertility. 
Table 1. BPA exposure and fertility related gene expression and genetic modification.

\begin{tabular}{|c|c|c|c|c|c|}
\hline Author and Year & Species & Treatment Period & Dose & Tested Tissue & Change of Gene Expression \\
\hline $\begin{array}{l}\text { Caserta, et al. } \\
2013[79]\end{array}$ & $\begin{array}{l}\text { Infertile } \\
\text { women }\end{array}$ & - & - & $\begin{array}{l}\text { peripheral blood } \\
\text { mononuclear cell }\end{array}$ & ESR1, ESR2,AhR, PXR up-regulation; AhR, PPAR $\gamma$ no difference \\
\hline \multirow{2}{*}{$\begin{array}{l}\text { Chao, et al. } \\
2012[80]\end{array}$} & \multirow{2}{*}{ Mice } & \multirow{2}{*}{$\begin{array}{l}\text { Postnatal day } 7-14 \\
\text { or } 5-20\end{array}$} & \multirow{2}{*}{$\begin{array}{l}20-40 \mathrm{ug} / \mathrm{kg} \text { per } \\
\text { day or per } 5 \text { days }\end{array}$} & Ovarian & ESR1 up-regulated; ESR2 no difference \\
\hline & & & & Oocytes & IGF $2 \Gamma$, PEG3 methylated sites decreased; H19 no difference \\
\hline \multirow{2}{*}{$\begin{array}{l}\text { Brieno-Enriquez, et al. } \\
2012 \text { [81] }\end{array}$} & \multirow{2}{*}{$\begin{array}{l}\text { Human } \\
\text { (fetuses) }\end{array}$} & \multirow[t]{2}{*}{ Cultured 7-21 days } & \multirow[t]{2}{*}{ 30umol/L } & Cultured oocytes & $\begin{array}{l}\text { Up-regulation: H2ax, Rpa, Spo11, ESR1, ESR2, ERRГ, Blm at } 14 \\
\text { day;No difference: Stra8, Nalp5, Smc1B, Sycp1 }\end{array}$ \\
\hline & & & & Cultured fibroblasts & Up-regulation: H2ax, Rpa, Blm, ESR1, ESR2, ERR, MIh1 at 21 day \\
\hline \multirow{2}{*}{$\begin{array}{l}\text { Li, et al. } \\
2014[87]\end{array}$} & \multirow{2}{*}{ Wistar rats } & \multirow{2}{*}{ Postnatal day 28-35 day } & 10 or $40 \mathrm{mg} / \mathrm{kg} /$ day & \multirow{2}{*}{ Ovarian } & FIGLA, H1FOO and AMH no difference \\
\hline & & & $160 \mathrm{mg} / \mathrm{kg} /$ day & & FIGLA, H1FOO down-regulation; AMH up-regulation \\
\hline \multirow{2}{*}{$\begin{array}{l}\text { Calhoun, et al. } \\
2014[88]\end{array}$} & \multirow{2}{*}{$\begin{array}{l}\text { Rhesus } \\
\text { Macaque }\end{array}$} & \multirow[t]{2}{*}{ Gestational day $100-165$} & \multirow{2}{*}{$\begin{array}{l}400 \mathrm{ug} / \mathrm{kg} / \mathrm{day} \\
\text { deuterated BPA }\end{array}$} & \multirow[t]{2}{*}{ Fetal uteri } & $\begin{array}{l}\text { Up-regulated: PDE11A, HOXC9, IGHMBP2, CSTL1, HOXC10, IL26, } \\
\text { KLK3, ALX3, DOK6, ABHD1, HOXC6, HOXC8, HOXC9, HOXC10, } \\
\text { HOXD1, HXOD3, HOXD9, WNT2, WNT4, WNT5A }\end{array}$ \\
\hline & & & & & $\begin{array}{l}\text { Down-regulated: CDH4, GDE1, GJB3, TFAP2C, RNF186, HOXA13, } \\
\text { FGF10, CLIC6, CXCL14, SST, HOXA13 }\end{array}$ \\
\hline \multirow[t]{2}{*}{$\begin{array}{l}\text { Susiarjo, et al. } \\
2013 \text { [89] }\end{array}$} & \multirow[t]{2}{*}{ Mice } & \multirow[t]{2}{*}{$\begin{array}{l}2 \text { weeks prior to mating } \\
\text { and embryonic }(\mathrm{E}) \\
\text { day } 0-9.5\end{array}$} & \multirow[t]{2}{*}{$\begin{array}{c}10 \mathrm{ug} \text { or } \\
10 \mathrm{mg} / \mathrm{kg} / \text { day }\end{array}$} & Placenta & $\begin{array}{l}\text { LOI: Snrpn, Kcnq1ot1 } \\
\text { Average total RNA (placentas with or without LOI) expression } \\
\text { up-regulated: Snrpn, Kcnq1ot1; Placentas with LOI had higher RNA } \\
\text { expression at lower dose: Snrpn; Average total RNA expression } \\
\text { down-regulated: Cdkn1c (upper dose and lower dose), Ube3a; } \\
\text { Methylation levels reduced: Snrpn,Kenq1ot1 }\end{array}$ \\
\hline & & & & Embryo & $\begin{array}{l}\text { LOI: Igf2 } \\
\text { Average total RNA expression up-regulated: Igf2; Methylation levels } \\
\text { increased: Igf2 DMR1; Methylation levels reduced: H19/Igf2 ICR }\end{array}$ \\
\hline
\end{tabular}


Brieno-Enriquezet et al. [81] found that the expression of genes involved in double-strand break generation (Spol1), signaling (H2ax) and repair (Rpa, Blm) increased significantly in cultured fetal oocytes treated with BPA during meiotic prophase (Table 1). This possible molecular mechanism may explain the effects of BPA on female germ cells [81]. An in vivo animal study [90] focusing on the effect of BPA on the expression of meiosis-related genes treated pregnant mice with BPA (20 ng/g/day) beginning at 11 days postcoitus (dpc). Fetal ovaries were collected at 12-, 12.5-, 13.5-, and 14.5-day in pregnancy. Sixteen meiosis-specific genes were selected: meiotic entry gene Stra8; Spo11, Sycp1, Sycp2, Sycp3, Syce1, Syce2 and Tex12 (associated with the formation of synaptonemal complex); Rec8, Stag3, Smclb (associated with sister chromatid cohesion), Dmc1, Mei1, Msh4, and Msh5, Prdm9 (meiotic recombination pathway genes). All of these genes were up-regulated after BPA treatment for 3.5 days, although only $M s h 4, D m c 1$, and Sycp 2 reached statistical significance. A dramatic increase in expression of all of the above genes was observed from 12 to $14.5 \mathrm{dpc}$. It raises the possibility that fetal BPA exposure may limit expansion of the primordial germ cell population.

Another in vivo rat study [87] showed a decrease in follicle number and an increase in constituent ratio of atretic follicles in relation to BPA levels. The alteration may be caused by the changed expression of follicle development-related genes such as FIGLA, HIFOO and AMH (Table 1) with increasing BPA doses. For example, compared with the 0 (control) group, the expression of FIGLA gene mRNA was significantly reduced in the $160 \mathrm{mg} / \mathrm{kg} /$ day BPA group while the expression of $A M H$ gene mRNA was significantly increased. However, H1FOO gene mRNA expression levels showed a significant decrease in all BPA groups. Whether these adverse effects and the potential mechanism are consistent with those in human needs further confirmation [87] as the dose used in this study was much higher than that of human exposure.

The expression levels of key development-related and functional genes of the uterus also have attracted great attention. When pregnant rhesus macaques were exposed to BPA at gestation day (GD) 100-165, significant differences in genes expression in fetal uteri were observed between BPA-exposed and placebo groups at GD165 (Table 1). It showed that BPA exposure in the third trimester could alter transcriptional signals and may, in turn, influence adult uterine function of the offspring. The article detailed the role of $H O X A 13$, WNT4 and WNT5A, which are critical for development and function of human reproductive organ [88]. The dose used in this study was $400 \mu \mathrm{g} / \mathrm{kg} / \mathrm{day}$, which resulted in unconjugated biologically active BPA of $0.3-0.5 \mathrm{ng} / \mathrm{mL}$ [56], which is similar to serum levels in human adults and fetuses [14].

Epigenetics may be another important mechanism of BPA-gene interaction in female infertility. The effects of epigenetic modifications generally include DNA methylation, histone modification (acetylation, methylation, phosphrylation, ubiquitination, sumoylation and ADP ribosylation), and expression of non-coding RNAs (including microRNA) [91]. Environmental toxicants may alter epigenome rather than DNA sequence [92]. Furthermore, the modification of the epigenome in the germ line might be transmitted to the progeny, therefore, promoting a transgenerational phenotype [92]. Chao et al. [80] evaluated the effects of BPA on the reprogramming of imprinted genes and found that the increased concentration of BPA remarkably decreased the methylation pattern of maternal imprinted genes (Table 1). Meanwhile, the expressions of four types of DNA methyltransferases (Dnmt1, Dnmt3a, Dnmt3b and Dnmt3L) were all suppressed with increasing BPA treatment concentrations. Another in vivo study [89] found maternal BPA exposure reduced the imprinted genes 
(Snrpn, Ube3a, Kcnqlot1, Cdkn1c, and Ascl2) methylation levels in mice placentas with the dose of dietary BPA at $10 \mathrm{mg} / \mathrm{kg} / \mathrm{day}$. The RNA expression of these genes increased. While methylation levels of $I g f 2$ in embryos were up-regulated, the RNA expression was down-regulated at the dose of $10 \mathrm{mg} / \mathrm{kg} /$ day BPA. Loss of imprinting (LOI) occurred at Snrpn, Kcnqlot1 and Igf2 (Table 1). It was hypothesized that DNA methylation may regulate the imprinting, but perfect correlation was not found in this study [89]. They suggested that abnormal development of the placenta and embryo disturbed fetal and postnatal health. Thus, the epigenome is vulnerable to environmental perturbations, particularly during embryogenesis, neonatal development, and adolescence via epigenetic mechanisms.

\section{Conclusions}

To sum up, animal studies have demonstrated that BPA can affect female fertility by directly altering reproduction-related gene expression as well as impacting epigenetic modification. Critical and sensitive windows of susceptibility include progestation, pregnancy, infancy, childhood and puberty [28]. However, it should be pointed out that different species, or different development periods of the same species, different doses of BPA exposure, and/or different exposure modes and times, can all widely influence study results in animals. There are also significant variations between and within human populations. Literature on the association between BPA and female infertility and its potential biological mechanisms is still limited. Evidence on gene-environment interaction is even more scarce. More research on this topic is warranted.

\section{Acknowledgments}

This review was supported by the China National Basic Science Research Program (Grant number 973 2014CB943300)

\section{Author Contributions}

Xiaona Huo designed the review, performed the literature search, extracted the data and drafted the manuscript. Jun Zhang helped draft the manuscript, critically revised and approved the final version. Dan Chen, Yonghua He, Wenting Zhu and Wei Zhou helped to revise it.

\section{Conflicts of Interest}

The authors declare no conflict of interest.

\section{Reference}

1. Giudice, L.C. Infertility and the environment: The medical context. Semin. Reprod. Med. 2006, 24, 129-133.

2. Liu, F.; Liu, W.N.; Zhao, Q.X.; Han, M.M. Study on environmental and psychological risk factors for female infertility. Zhonghua Lao Dong Wei Sheng Zhi Ye Bing Za Zhi 2013, 31, 922-923 (In Chinese). 
3. Nishikawa, M.; Iwano, H.; Yanagisawa, R.; Koike, N.; Inoue, H.; Yokota, H. Placental transfer of conjugated bisphenol A and subsequent reactivation in the rat fetus. Environ. Health Perspect. 2010, 118, 1196-1203.

4. Dang, V.H.; Choi, K.C.; Jeung, E.B. Tetrabromodiphenyl ether (BDE 47) evokes estrogenicity and calbindin-D9k expression through an estrogen receptor-mediated pathway in the uterus of immature rats. Toxicol. Sci. 2007, 97, 504-511.

5. Choi, K.C.; Jeung, E.B. The biomarker and endocrine disruptors in mammals. J. Reprod. Dev. 2003, 49, 337-345.

6. Calafat, A.M.; Kuklenyik, Z.; Reidy, J.A.; Caudill, S.P.; Ekong, J.; Needham, L.L. Urinary concentrations of bisphenol A and 4-nonylphenol in a human reference population. Environ. Health Perspect. 2004, 113, 391-395.

7. Tyl, R.W. Abbreviated assessment of bisphenol A toxicology literature. Semin. Fetal Neonatal Med. 2014, 19, 195-202.

8. Teeguarden, J.G.; Hanson-Drury, S. A systematic review of Bisphenol A "low dose" studies in the context of human exposure: A case for establishing standards for reporting "low-dose" effects of chemicals. Food Chem. Toxicol. 2013, 62, 935-948.

9. Rochester, J.R. Bisphenol A and human health: A review of the literature. Reprod. Toxicol. 2013, 42, 132-155.

10. Chapin, R.E.; Adams, J.; Boekelheide, K.; Gray, L.E., Jr.; Hayward, S.W.; Lees, P.S.; McIntyre, B.S.; Portier, K.M.; Schnorr, T.M.; Selevan, S.G.; et al. NTP-CERHR expert panel report on the reproductive and developmental toxicity of bisphenol A. Birth Defects Res. B Dev. Reprod. Toxicol. 2008, 83, 157-395.

11. Avissar-Whiting, M.; Veiga, K.R.; Uhl, K.M.; Maccani, M.A.; Gagne, L.A.; Moen, E.L.; Marsit, C.J. Bisphenol A exposure leads to specific microRNA alterations in placental cells. Reprod. Toxicol. 2010, 29, 401-406.

12. Bhan, A.; Hussain, I.; Ansari, K.I.; Bobzean, S.A.; Perrotti, L.I.; Mandal, S.S. Bisphenol-A and diethylstilbestrol exposure induces the expression of breast cancer associated long noncoding RNA HOTAIR in vitro and in vivo. J. Steroid Biochem. Mol. Biol. 2014, 141, 160-170.

13. Dodson, R.E.; Nishioka, M.; Standley, L.J.; Perovich, L.J.; Brody, J.G.; Rudel, R.A. Endocrine disruptors and asthma-associated chemicals in consumer products. Environ. Health Perspect. 2012, 120, 935-943.

14. Vandenberg, L.N.; Chahoud, I.; Heindel, J.J.; Padmanabhan, V.; Paumgartten, F.J.; Schoenfelder, G. Urinary, circulating, and tissue biomonitoring studies indicate widespread exposure to bisphenol A. Cien. Saude Colet. 2012, 17, 407-434.

15. Gregoraszczuk, E.L.; Ptak, A. Endocrine-disrupting chemicals: Some actions of POPs on female reproduction. Int. J. Endocrinol. 2013, 2013, 1-9.

16. Newbold, R.R.; Jefferson, W.N.; Padilla-Banks, E. Prenatal exposure to bisphenol a at environmentally relevant doses adversely affects the murine female reproductive tract later in life. Environ. Health Perspect. 2009, 117, 879-885.

17. Vandenberg, L.N.; Hauser, R.; Marcus, M.; Olea, N.; Welshons, W.V. Human exposure to bisphenol A (BPA). Reprod. Toxicol. 2007, 24, 139-177. 
18. Schonfelder, G.; Wittfoht, W.; Hopp, H.; Talsness, C.E.; Paul, M.; Chahoud, I. Parent bisphenol A accumulation in the human maternal-fetal-placental unit. Environ. Health Perspect. 2002, 110, $703-707$.

19. Fung, E.Y.; Ewoldsen, N.O.; St Germain, H.A., Jr.; Marx, D.B.; Miaw, C.L.; Siew, C.; Chou, H.N.; Gruninger, S.E.; Meyer, D.M. Pharmacokinetics of bisphenol A released from a dental sealant. J. Am. Dent. Assoc. 2000, 131, 51-58.

20. Ikezuki, Y.; Tsutsumi, O.; Takai, Y.; Kamei, Y.; Taketani, Y. Determination of bisphenol A concentrations in human biological fluids reveals significant early prenatal exposure. Hum. Reprod. 2002, 17, 2839-2841.

21. Volkel, W.; Colnot, T.; Csanady, G.A.; Filser, J.G.; Dekant, W. Metabolism and kinetics of bisphenol A in humans at low doses following oral administration. Chem. Res. Toxicol. 2002, 15, 1281-1287.

22. Ginsberg, G.; Rice, D.C. Does rapid metabolism ensure negligible risk from bisphenol A? Environ. Health Perspect. 2009, 117, 1639-1643.

23. Williams, S.A.; Jasarevic, E.; Vandas, G.M.; Warzak, D.A.; Geary, D.C.; Ellersieck, M.R.; Roberts, R.M.; Rosenfeld, C.S. Effects of developmental bisphenol A exposure on reproductive-related behaviors in California mice (Peromyscus californicus): A monogamous animal model. PLoS ONE 2013, 8, doi:10.1371/journal.pone.0055698.

24. MacLusky, N.J.; Hajszan, T.; Leranth, C. The environmental estrogen bisphenol A inhibits estradiol-induced hippocampal synaptogenesis. Environ. Health Perspect. 2005, 113, 675-679.

25. Nagel, S.C.; vom Saal, F.S.; Thayer, K.A.; Dhar, M.G.; Boechler, M.; Welshons, W.V. Relative binding affinity-serum modified access (RBA-SMA) assay predicts the relative in vivo bioactivity of the xenoestrogens bisphenol A and octylphenol. Environ. Health Perspect. 1997, 105, 70-76.

26. Vom Saal, F.S.; Timms, B.G.; Montano, M.M.; Palanza, P.; Thayer, K.A.; Nagel, S.C.; Dhar, M.D.; Ganjam, V.K.; Parmigiani, S.; Welshons, W.V. Prostate enlargement in mice due to fetal exposure to low doses of estradiol or diethylstilbestrol and opposite effects at high doses. Proc. Natl. Acad. Sci. USA 1997, 94, 2056-2061.

27. Machtinger, R.; Orvieto, R. Bisphenol A, oocyte maturation, implantation, and IVF outcome: Review of animal and human data. Reprod. Biomed. Online 2014, 29, 404-410.

28. Woodruff, T.J.; Carlson, A.; Schwartz, J.M.; Giudice, L.C. Proceedings of the summit on environmental challenges to reproductive health and fertility: Executive summary. Fertil. Steril. 2008, 89, 281-300.

29. Cates, W. Preserving fertility. Network 2003, 23, 9-10.

30. Damario, M.A. General aspects of fertility and infertility. Methods Mol. Biol. 2014, 1154, 3-23.

31. Forti, G.; Krausz, C. Evaluation and treatment of the infertile couple 1. J. Clin. Endocrinol. Metab. 1998, 83, 4177-4188.

32. Gore, A.C. Developmental programming and endocrine disruptor effects on reproductive neuroendocrine systems. Front. Neuroendocrinol. 2008, 29, 358-374.

33. Tena-Sempere, M. Kisspeptin/GPR54 system as potential target for endocrine disruption of reproductive development and function. Int. J. Androl. 2010, 33, 360-368. 
34. Fernández, M.; Bourguignon, N.; Lux-Lantos, V.; Libertun, C. Neonatal exposure to bisphenol A and reproductive and endocrine alterations resembling the polycystic ovarian syndrome in adult rats. Environ. Health Perspect. 2010, 118, 1217-1222.

35. Tena-Sempere, M.; Felip, A.; Gomez, A.; Zanuy, S.; Carrillo, M. Comparative insights of the kisspeptin/kisspeptin receptor system: Lessons from non-mammalian vertebrates. Gen. Comp. Endocrinol. 2012, 175, 234-243.

36. Selvaraj, S.; Kitano, H.; Ohga, H.; Yamaguchi, A.; Matsuyama, M. Expression changes of mRNAs encoding kisspeptins and their receptors and gonadotropin-releasing hormones during early development and gonadal sex differentiation periods in the brain of chub mackerel (Scomber japonicus). Gen. Comp. Endocrinol. 2014, doi:10.1016/j.ygcen.2014.09.019.

37. Navarro, V.M.; Sanchez-Garrido, M.A.; Castellano, J.M.; Roa, J.; Garcia-Galiano, D.; Pineda, R.; Aguilar, E.; Pinilla, L.; Tena-Sempere, M. Persistent impairment of hypothalamic KiSS-1 system after exposures to estrogenic compounds at critical periods of brain sex differentiation. Endocrinology 2009, 150, 2359-2367.

38. Diamanti-Kandarakis, E.; Bourguignon, J.P.; Giudice, L.C.; Hauser, R.; Prins, G.S.; Soto, A.M.; Zoeller, R.T.; Gore, A.C. Endocrine-disrupting chemicals: An Endocrine Society scientific statement. Endocr. Rev. 2009, 30, 293-342.

39. Mahoney, M.M.; Padmanabhan, V. Developmental programming: Impact of fetal exposure to endocrine-disrupting chemicals on gonadotropin-releasing hormone and estrogen receptor mRNA in sheep hypothalamus. Toxicol. Appl. Pharmacol. 2010, 247, 98-104.

40. Brannick, K.E.; Craig, Z.R.; Himes, A.D.; Peretz, J.R.; Wang, W.; Flaws, J.A.; Raetzman, L.T. Prenatal exposure to low doses of bisphenol A increases pituitary proliferation and gonadotroph number in female mice offspring at birth. Biol. Reprod. 2012, 87, doi:10.1095/biolreprod.112. 100636.

41. Wu, S.; Wilson, M.D.; Busby, E.R.; Isaac, E.R.; Sherwood, N.M. Disruption of the single copy gonadotropin-releasing hormone receptor in mice by gene trap: Severe reduction of reproductive organs and functions in developing and adult mice. Endocrinology 2010, 151, 1142-1152.

42. Richard, N.; Galmiche, G.; Corvaisier, S.; Caraty, A.; Kottler, M.L. KiSS-1 and GPR54 genes are co-expressed in rat gonadotrophs and differentially regulated in vivo by oestradiol and gonadotrophin-releasing hormone. J. Neuroendocrinol. 2008, 20, 381-393.

43. Souter, I.; Smith, K.W.; Dimitriadis, I.; Ehrlich, S.; Williams, P.L.; Calafat, A.M.; Hauser, R. The association of bisphenol-A urinary concentrations with antral follicle counts and other measures of ovarian reserve in women undergoing infertility treatments. Reprod. Toxicol. 2013, 42, 224-231.

44. Brieno-Enriquez, M.A.; Robles, P.; Camats-Tarruella, N.; Garcia-Cruz, R.; Roig, I.; Cabero, L.; Martinez, F.; Caldes, M.G. Human meiotic progression and recombination are affected by bisphenol A exposure during in vitro human oocyte development. Hum. Reprod. 2011, 26, 2807-2818.

45. Manikkam, M.; Tracey, R.; Guerrero-Bosagna, C.; Skinner, M.K. Plastics derived endocrine disruptors (BPA, DEHP and DBP) induce epigenetic transgenerational inheritance of obesity, reproductive disease and sperm epimutations. PLOS ONE 2013, 8, doi:10.1371/journal.pone. 0055387. 
46. Diamanti-Kandarakis, E.; Kouli, C.R.; Bergiele, A.T.; Filandra, F.A.; Tsianateli, T.C.; Spina, G.G.; Zapanti, E.D.; Bartzis, M.I. A survey of the polycystic ovary syndrome in the Greek island of Lesbos: Hormonal and metabolic profile. J. Clin. Endocrinol. Metab. 1999, 84, 4006-4011.

47. Brown, M.A.; Chang, R.J. Polycystic ovary syndrome: Clinical and imaging features. Ultrasound Quart. 2007, 23, 233-238.

48. Akın, L.; Kendirci, M.; Narin, F.; Kurtoglu, S.; Saraymen, R.; Kondolot, M.; Koçak, S.; Elmalı, F. The endocrine disruptor bisphenol A may play a role in the aetiopathogenesis of polycystic ovary syndrome in adolescent girls. Acta Paediatr. 2015, 104, 171-177.

49. Kandaraki, E.; Chatzigeorgiou, A.; Livadas, S.; Palioura, E.; Economou, F.; Koutsilieris, M.; Palimeri, S.; Panidis, D.; Diamanti-Kandarakis, E. Endocrine disruptors and polycystic ovary syndrome (PCOS): Elevated serum levels of bisphenol A in women with PCOS. J. Clin. Endocrinol. Metab. 2011, 96, 480-484.

50. Zhou, W.; Liu, J.; Liao, L.; Han, S. Effect of bisphenol A on steroid hormone production in rat ovarian theca-interstitial and granulosa cells. Mol. Cell. Endocrinol. 2008, 283, 12-18.

51. Hanioka, N.; Jinno, H.; Nishimura, T.; Ando, M. Suppression of male-specific cytochrome P450 isoforms by bisphenol A in rat liver. Arch. Toxicol. 1998, 72, 387-394.

52. Takeuchi, T.; Tsutsumi, O.; Ikezuki, Y.; Kamei, Y.; Osuga, Y.; Fujiwara, T.; Takai, Y.; Momoeda, M.; Yano, T.; Taketani, Y. Elevated serum bisphenol A levels under hyperandrogenic conditions may be caused by decreased UDP-glucuronosyltransferase activity. Endocr. J. 2006, $53,485-491$.

53. Guillemette, C.; Levesque, E.; Beaulieu, M.; Turgeon, D.; Hum, D.W.; Belanger, A. Differential regulation of two uridine diphospho-glucuronosyltransferases, UGT2B15 and UGT2B17, in human prostate LNCaP cells. Endocrinology 1997, 138, 2998-3005.

54. Takeuchi, T.; Tsutsumi, O. Serum bisphenol A concentrations showed gender differences, possibly linked to androgen levels. Biochem. Biophys. Res. Commun. 2002, 291, 76-78.

55. Alonso-Magdalena, P.; Morimoto, S.; Ripoll, C.; Fuentes, E.; Nadal, A. The estrogenic effect of bisphenol A disrupts pancreatic $\beta$-cell function in vivo and induces insulin resistance. Environ. Health Perspect. 2005, 114, 106-112.

56. Hunt, P.A.; Lawson, C.; Gieske, M.; Murdoch, B.; Smith, H.; Marre, A.; Hassold, T.; VandeVoort, C.A. Bisphenol A alters early oogenesis and follicle formation in the fetal ovary of the rhesus monkey. Proc. Natl. Acad. Sci. USA 2012, 109, 17525-17530.

57. Machtinger, R.; Combelles, C.M.; Missmer, S.A.; Correia, K.F.; Williams, P.; Hauser, R.; Racowsky, C. Bisphenol-A and human oocyte maturation in vitro. Hum. Reprod. 2013, 28, 2735-2745.

58. Hunt, P.A.; Koehler, K.E.; Susiarjo, M.; Hodges, C.A.; Ilagan, A.; Voigt, R.C.; Thomas, S.; Thomas, B.F.; Hassold, T.J. Bisphenol A exposure causes meiotic aneuploidy in the female mouse. Curr. Biol. 2003, 13, 546-553.

59. Eichenlaub-Ritter, U.; Vogt, E.; Cukurcam, S.; Sun, F.; Pacchierotti, F.; Parry, J. Exposure of mouse oocytes to bisphenol A causes meiotic arrest but not aneuploidy. Mutat. Res. 2008, 651, 82-92. 
60. Newbold, R.R.; Jefferson, W.N.; Padilla-Banks, E. Long-term adverse effects of neonatal exposure to bisphenol A on the murine female reproductive tract. Reprod. Toxicol. 2007, 24, 253-258.

61. Signorile, P.G.; Spugnini, E.P.; Mita, L.; Mellone, P.; D’Avino, A.; Bianco, M.; Diano, N.; Caputo, L.; Rea, F.; Viceconte, R.; et al. Pre-natal exposure of mice to bisphenol A elicits an endometriosis-like phenotype in female offspring. Gen. Comp. Endocrinol. 2010, 168, 318-325.

62. Buck Louis, G.M.; Peterson, C.M.; Chen, Z.; Croughan, M.; Sundaram, R.; Stanford, J.; Varner, M.W.; Kennedy, A.; Giudice, L.; Fujimoto, V.Y.; et al. Bisphenol A and phthalates and endometriosis: The Endometriosis: Natural History, Diagnosis and Outcomes Study. Fertil. Steril. 2013, 100, 162-169.

63. Hiroi, H.; Tsutsumi, O.; Takeuchi, T.; Momoeda, M.; Ikezuki, Y.; Okamura, A.; Yokota, H.; Taketani, Y. Differences in serum bisphenol a concentrations in premenopausal normal women and women with endometrial hyperplasia. Endocr. J. 2004, 51, 595-600.

64. Itoh, H.; Iwasaki, M.; Hanaoka, T.; Sasaki, H.; Tanaka, T.; Tsugane, S. Urinary bisphenol-A concentration in infertile Japanese women and its association with endometriosis: A cross-sectional study. Environ. Health Prev. Med. 2007, 12, 258-264.

65. Varayoud, J.; Ramos, J.G.; Bosquiazzo, V.L.; Lower, M.; Munoz-de-Toro, M.; Luque, E.H. Neonatal exposure to bisphenol A alters rat uterine implantation-associated gene expression and reduces the number of implantation sites. Endocrinology 2011, 152, 1101-1111.

66. Bromer, J.G.; Zhou, Y.; Taylor, M.B.; Doherty, L.; Taylor, H.S. Bisphenol-A exposure in utero leads to epigenetic alterations in the developmental programming of uterine estrogen response. FASEB J. 2010, 24, 2273-2280.

67. Xiao, S.; Diao, H.; Smith, M.A.; Song, X.; Ye, X. Preimplantation exposure to bisphenol A (BPA) affects embryo transport, preimplantation embryo development, and uterine receptivity in mice. Reprod. Toxicol. 2011, 32, 434-441.

68. Berger, R.G.; Foster, W.G.; deCatanzaro, D. Bisphenol-A exposure during the period of blastocyst implantation alters uterine morphology and perturbs measures of estrogen and progesterone receptor expression in mice. Reprod. Toxicol. 2010, 30, 393-400.

69. Berger, R.G.; Shaw, J.; deCatanzaro, D. Impact of acute bisphenol-A exposure upon intrauterine implantation of fertilized ova and urinary levels of progesterone and 17beta-estradiol. Reprod. Toxicol. 2008, 26, 94-99.

70. Minguez-Alarcon, L.; Gaskins, A.J.; Chiu, Y.H.; Williams, P.L.; Ehrlich, S.; Chavarro, J.E.; Petrozza, J.C.; Ford, J.B.; Calafat, A.M.; Hauser, R. Urinary bisphenol A concentrations and association with in vitro fertilization outcomes among women from a fertility clinic. Hum. Reprod. 2015, 30, 2120-2128.

71. Robins, J.C.; Marsit, C.J.; Padbury, J.F.; Sharma, S.S. Endocrine disruptors, environmental oxygen, epigenetics and pregnancy. Front. Biosci. 2011, 3, 690-700.

72. Axelsson, J.; Bonde, J.P.; Giwercman, Y.L.; Rylander, L.; Giwercman, A. Gene-environment interaction and male reproductive function. Asian J. Androl. 2010, 12, 298-307.

73. Dada, R.; Kumar, M.; Jesudasan, R.; Fernandez, J.L.; Gosalvez, J.; Agarwal, A. Epigenetics and its role in male infertility. J. Assist. Reprod. Genet. 2012, 29, 213-223. 
74. Macon, M.B.; Fenton, S.E. Endocrine disruptors and the breast: Early life effects and later life disease. J. Mammary Gland Biol. Neoplasia 2013, 18, 43-61.

75. Newbold, R.R.; Padilla-Banks, E.; Jefferson, W.N. Adverse effects of the model environmental estrogen diethylstilbestrol are transmitted to subsequent generations. Endocrinology 2006, 147, $11-17$.

76. Costa, E.M.F.; Spritzer, P.M.; Hohl, A.; Bachega, T.A.S.S. Effects of endocrine disruptors in the development of the female reproductive tract. Arq. Bras. Endocrinol. Metabol. 2014, 58, 153-161.

77. Maruyama, K.; Nakamura, M.; Tomoshige, S.; Sugita, K.; Makishima, M.; Hashimoto, Y.; Ishikawa, M. Structure-activity relationships of bisphenol A analogs at estrogen receptors (ERs): Discovery of an ERalpha-selective antagonist. Bioorg. Med. Chem. Lett. 2013, 23, 4031-4036.

78. Welshons, W.V.; Nagel, S.C.; vom Saal, F.S. Large effects from small exposures. III. Endocrine mechanisms mediating effects of bisphenol A at levels of human exposure. Endocrinology 2006, 147, 56-69.

79. Caserta, D.; Ciardo, F.; Bordi, G.; Guerranti, C.; Fanello, E.; Perra, G.; Borghini, F.; La Rocca, C.; Tait, S.; Bergamasco, B.; et al. Correlation of endocrine disrupting chemicals serum levels and white blood cells gene expression of nuclear receptors in a population of infertile women. Int. J. Endocrinol. 2013, 2013, doi:10.1155/2013/510703.

80. Chao, H.H.; Zhang, X.F.; Chen, B.; Pan, B.; Zhang, L.J.; Li, L.; Sun, X.F.; Shi, Q.H.; Shen, W. Bisphenol A exposure modifies methylation of imprinted genes in mouse oocytes via the estrogen receptor signaling pathway. Histochem. Cell Biol. 2012, 137, 249-259.

81. Brieno-Enriquez, M.A.; Reig-Viader, R.; Cabero, L.; Toran, N.; Martinez, F.; Roig, I.; Garcia Caldes, M. Gene expression is altered after bisphenol A exposure in human fetal oocytes in vitro. Mol. Hum. Reprod. 2012, 18, 171-183.

82. Moral, R.; Wang, R.; Russo, I.H.; Lamartiniere, C.A.; Pereira, J.; Russo, J. Effect of prenatal exposure to the endocrine disruptor bisphenol A on mammary gland morphology and gene expression signature. J. Endocrinol. 2008, 196, 101-112.

83. Anway, M.D.; Skinner, M.K. Epigenetic programming of the germ line: Effects of endocrine disruptors on the development of transgenerational disease. Reprod. Biomed. Online 2008, 16, 23-25.

84. Schug, T.T.; Janesick, A.; Blumberg, B.; Heindel, J.J. Endocrine disrupting chemicals and disease susceptibility. J. Steroid Biochem. Mol. Biol. 2011, 127, 204-215.

85. Melzer, D.; Harries, L.; Cipelli, R.; Henley, W.; Money, C.; McCormack, P.; Young, A.; Guralnik, J.; Ferrucci, L.; Bandinelli, S.; et al. Bisphenol A exposure is associated with in vivo estrogenic gene expression in adults. Environ. Health Perspect. 2011, 119, 1788-1793.

86. Caserta, D.; Bordi, G.; Ciardo, F.; Marci, R.; La Rocca, C.; Tait, S.; Bergamasco, B.; Stecca, L.; Mantovani, A.; Guerranti, C.; et al. The influence of endocrine disruptors in a selected population of infertile women. Gynecol. Endocrinol. 2013, 29, 444-447.

87. Li, Y.; Zhang, W.; Liu, J.; Wang, W.; Li, H.; Zhu, J.; Weng, S.; Xiao, S.; Wu, T. Prepubertal bisphenol A exposure interferes with ovarian follicle development and its relevant gene expression. Reprod. Toxicol. 2014, 44, 33-40. 
88. Calhoun, K.C.; Padilla-Banks, E.; Jefferson, W.N.; Liu, L.; Gerrish, K.E.; Young, S.L.; Wood, C.E.; Hunt, P.A.; Vandevoort, C.A.; Williams, C.J. Bisphenol A exposure alters developmental gene expression in the fetal rhesus macaque uterus. PLoS ONE 2014, 9, doi:10.1371/journal.pone.0085894.

89. Susiarjo, M.; Sasson, I.; Mesaros, C.; Bartolomei, M.S. Bisphenol A exposure disrupts genomic imprinting in the mouse. PLoS Genet. 2013, 9, doi:10.1371/journal.pgen.1003401.

90. Lawson, C.; Gieske, M.; Murdoch, B.; Ye, P.; Li, Y.; Hassold, T.; Hunt, P.A. Gene expression in the fetal mouse ovary is altered by exposure to low doses of bisphenol A. Biol. Reprod. 2011, 84, 79-86.

91. Singh, S.; Li, S.S. Epigenetic effects of environmental chemicals bisphenol a and phthalates. Int. J. Mol. Sci. 2012, 13, 10143-10153.

92. Skinner, M.K.; Manikkam, M.; Guerrero-Bosagna, C. Epigenetic transgenerational actions of endocrine disruptors. Reprod. Toxicol. 2011, 31, 337-343.

(C) 2015 by the authors; licensee MDPI, Basel, Switzerland. This article is an open access article distributed under the terms and conditions of the Creative Commons Attribution license (http://creativecommons.org/licenses/by/4.0/). 